\title{
Socially Responsible Investment And Macroeconomic Stability In South Africa: An Application Of Vector Error Correction Model
}

Paul F. Muzindutsi, North-West University, South Africa

Tshediso J. Sekhampu, North-West University, South Africa

\begin{abstract}
The study reported in this article investigated the relationship between the Social Responsible Investment (SRI) sector and macroeconomic stability in South Africa. Johansen co-integration approach and Vector Error Correction Model (VECM) were employed to test the relationship between SRI Index and a set of macroeconomic stability variables (inflation, real exchange rate, interest rates and money supply). Secondary data for the period April 2004 to December 2012 was analysed. There was a long-run association between all the variables during the period under consideration. However, the inflation rate, real effective exchange rate and money supply were not significant in predicting short-run changes in the SRI Index. A significant short-run relationship between SRI Index and the difference between long term and short-term interest rates (term structure) was observed. Macroeconomic variables are significant in explaining the behavior of the South African SRI sector in the long-run.
\end{abstract}

Keywords: Socially Responsible Investment; Co-Integration; Vector Error Correction; South Africa

\section{INTRODUCTION}

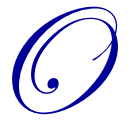

ne of the growing areas of the South African stock market development is the Socially Responsible Investment (SRI) sector. In the South African context, SRIs are mostly based on the implementation of good corporate governance to promote sustainability. Sustainability is categorised into three pillars, namely: environmental, economic, and social sustainability (JSE (Johannesburg Stock Exchange), 2004). Environmental sustainability encourages companies to use resources wisely in order to promote sustainable development of the country. Economic sustainability involves good corporate governance practices that encourage long-term financial performance while adapting to changes in macroeconomic factors and ensuring feasibility of the business (JSE, 2011:4). Social sustainability entails the establishment and maintenance of a positive relationship with all stakeholders. This involves development of strategies that promote social upliftment, development and poverty reduction, while taking account of diversity, employment equity, empowerment, fair labour practices and health and safety (JSE, 2004). In responding to the growing interest in responsible investment around the world, the Johannesburg Stock Exchange (JSE) launched a Socially Responsible Index (SRI) in May 2004. The SRI Index serves a useful tool for companies and investors to achieve the goal of sustainability by respecting the community and environment in which they operate in (JSE, 2009).

The development of the JSE SRI Index plays an important role in encouraging companies to increase their involvement in SRI initiatives (JSE, 2012). In 2001, for example, a number of South Africa companies implemented, coordinated and managed various sustainable development initiatives in the areas of education and training, capacity building, community support and health (Flores-Araoz, 2011). This highlights the role of the South African SRI sector in promoting economic development through investment in infrastructural development, healthcare and educational initiatives. Thus, SRI initiatives my affect (or be affected by) changes in the 
macroeconomic environment, seen as macroeconomic stability. Macroeconomic stability describes a national economy that has minimized vulnerability to external shocks, which in turn increases its prospects for sustained growth. This link between South African macro-economic variables (such as economic growth, interest rate, unemployment, inflation and exchange rate) and the demand for SRIs has been suggested (Viviers et al., 2008); but not yet tested. The objective of this study is to assess the role of macroeconomic stability variables in explaining the behavior of the growing SRI sector in South Africa. The remainder of the article is organized as follows: section 2 provides a brief outline of the SRI sector; the methodology is presented in section 3, section 4 provides the empirical results, and section 5 concludes the article.

\section{A BRIEF OUTLINE OF SOCIALLY RESPONSIBLE INVESTMENT INDEX}

The origin of what is known as SRI goes back hundreds of years when Jewish law put down numerous directions about how to invest ethically (Schueth, 2006; Herringer, 2009). For generations, religious investors have avoided investing in businesses that profit from enslavement or war (Renneboog et al., 2007). The awareness of social responsibility and accountability increased during 1970s and 1980s as a result of concerns regarding wars, civil rights and equality for women, labour management issues and anti-nuclear convictions (Schueth, 2006). For example, in the1980s, millions of socially concerned investors used investment strategies to pursue the South African government to stop its racist system of apartheid (; Schueth, 2006; Renneboog et al. 2007). Since the 1990s, SRI sector has experienced a remarkable growth globally. Recent literature (Schuer, 2006; Vivier, 2007) use three key pillars to define SRI inclined investment decisions; namely- screening, shareholder advocacy and community. Screening involves the process of analysing companies' policies and attitude in order to determine whether their practices are in line with investor's personal values and social priorities. Shareholder advocacy or activism focuses on how shareholders influence corporate behaviour positively by engaging with management on issues of social sustainability, while community investment focusses on channeling capital investment toward community development activities in order to alleviate social hardships (Schuer, 2006). At the end of 2012, the total worth of global SRI was estimated to be US $\$ 13.6$ trillion and represented 21.8 percent of the total global assets managed professionally (Global Sustainable Investment Alliance (GSIA), 2013). SRI in Africa was estimated to be approximately US\$ 228.7 billion at the end of 2012, with South Africa representing about 95 percent of the SRI market in Sub-Saharan Africa (GSIA, 2013). This dominance of South Africa in the Sub-Saharan SRI sector was enhanced by the increased availability of SRI opportunity because of the availability of the JSE SRI Index (Viviers, 2007).

Economic theory suggests that stock prices should reflect expectations about future companies' performance, and companies' profits generally reflect the level of economic activities (Maysami, et al., 2004). This indicates that there should be a relationship between macroeconomic variables and aggregate stock market or stock market sector indices. This relationship has been documented by previous studies (Garcia \& Liu, 1999; Jefferis \& Okeahalam, 2000; Nacuer et al., 2008; Yang \& Yi, 2008; Yartey, 2008; Gupta \& Modise, 2011). Garcia and Liu (1999) tested the macroeconomic determinants of stock market development in a sample of Latin American and Asian countries. Their findings show that domestic investment, the growth of GDP per capita, and financial intermediary sector development are important predictors of the stock market development. On the same topic, Naceur et al. (2007) concluded that the savings rate, financial intermediary, and stock market liquidity are important determinants of stock market developments. Using Johansen co-integration technique, Kemboi \& Tarus (2012) concluded that macro-economic factors are important determinants of the development of the stock market in Kenya. A recent study by Gupta \& Modise (2011) used predictive regression framework to examine the importance of macroeconomic variables in explaining the behaviour of South African stock market returns and conluded that macroeconomic variables seemed not to predict stock returns. Additonally, other studies focused on the link between macroeconomic variables and individual companies or stock market's sectors such as the financial index, the property sector, industial sector and ressource sector (Reese, 1993; Dominguez \& Tesar, 2001; Maysami et al., 2004; Muzindutsi \& Niyimbanira, 2012). The general conlusion fom these studies is that stock market sectors respond differently to changes in macroeconomic variables. Since the SRI is considered as sector of the stock market, it is important to establish the response of the SRI Index to macroeconomic variables. 
Studies conducted on the SRI in South Africa focused mostly on the growth of the SRI sector, the challenges facing this sector and its performance relative to their benchmark (Viviers, 2007; Viviers et al., 2008; Williams, 2007; Herringer et al., 2009; Gladysek \& Chipeta, 2012). Viviers et al. (2008) identified two challenges facing the South African SRI sector namely, the relatively small size of the SRI industry and the institutional investors' lack of interest in committing substantial investments into SRI stocks. Other challenges that hinder the SRI industry growth are the negative perception of achieving a below-average return, the amount of human capital required to screen investments, the limited SRI universe, the lack of accessibility to SRI information and the lack of pension fund interest (Herringer et al., 2009). A study by Gladysek \& Chipeta (2012) used the event study methodology to examine the effects of SRI Index constituents announcements on the values of firms listed on the SRI Index from 2004 to 2009 and concluded that there were no significant abnormal returns associated with investing in the SRI Index. Due to limitations of data (Viviers et al., 2008), the relationship between the South African SRI sector and macroeconomic variables was not tested. Thus, the aim of this study is to close this gap by using more long term data (using a vector Error Correction Model (VCM)) to establish this relationship.

\section{DATA AND MODEL}

Data for this study is based on 104 monthly (May 2004 to December 2012) observations of SRI Index share prices and macroeconomic stability variables. The SRI Index (the proxy for South African SRI Sector) was launched in May 2004. Given that inflation has been used to measure macroeconomic stability (Garcia \& Liu, 1999; Kemboi \& Tarus, 2012; Nacuer, et al., 2008), this study selected macroeconomic stability variables closely related to inflation. Variables selected include the consumer price index (CPI), exchange rate, money supply and term spread (interest on long-term government bond - Treasury bill rate). Data on these macroeconomic variables were obtained from the South African Reserve Bank (SARB) and Statistics South Africa (STATS SA), while the SRI Index was accessed from McGregor BFA library. Variables were adjusted for inflation to obtain the real values, except for the real effective exchange rate index because it was given in real values.

The general econometric model used in this study is:

$\mathrm{SRI}=\mathrm{f}(\mathrm{TS}, \mathrm{CPI}, \mathrm{ER}, \mathrm{M} 3)$

where: SRI is the real value of SRI Index, TS is term spread, CPI is the consumer price index, ER is the real effective exchange rate and M3 is real money supply. Changing the above model to the logarithmic model we get the following model:

$\mathrm{LSRI}_{\mathrm{t}}=\mathrm{LTS}_{\mathrm{t}}+\mathrm{LCPI}_{\mathrm{t}}+\mathrm{LER}_{\mathrm{t}}+\mathrm{LM}_{\mathrm{t}}+\mathrm{u}_{\mathrm{t}}$

where: LSRI is the $\log$ of the real value of SRI Index, LTS is the $\log$ of real term spread, LCPI is the $\log$ of consumer price index, LER is the log of real effective exchange rate and LM3 is the log of real money supply. Considering that the dependent variable $\left(L S R I_{t}\right)$ may be related to its own lag values and to those of independent variables; a Vector Autoregressive (VAR) model was used in modelling the multivariate relationships between SRI Index and macroeconomic stability variables (Patterson, 2000). According to Chan (2010) and Maddala (2001), the VAR is a form of starting point for different analysis such as co-integration analysis, causality test, stability test, and impulse response. The VAR model for this paper is as follows:

$$
\begin{aligned}
& \operatorname{LSRI}_{\mathrm{t}}=\alpha_{1}+\sum_{\mathrm{j}=1}^{\mathrm{k}} \beta_{1 \mathrm{j}} \mathrm{SRI}_{\mathrm{t}-\mathrm{j}}+\sum_{\mathrm{j}=1}^{\mathrm{k}} \lambda_{1 \mathrm{j}} \mathrm{LTS}_{\mathrm{t}-\mathrm{j}}+\sum_{\mathrm{j}=1}^{\mathrm{k}} \gamma_{1 \mathrm{j}} \operatorname{LINF}_{\mathrm{t}-\mathrm{j}} \sum_{\mathrm{j}=1}^{\mathrm{k}} \delta_{1 \mathrm{j}} \mathrm{LER}_{\mathrm{t}-\mathrm{j}}+\sum_{\mathrm{j}=1}^{\mathrm{k}} \theta_{1 \mathrm{j}} \mathrm{LM}_{\mathrm{t}-\mathrm{j}}+\mathrm{u}_{1 \mathrm{t}} \\
& \operatorname{LTS}_{\mathrm{t}}=\alpha_{2}+\sum_{\mathrm{j}=1}^{\mathrm{k}} \beta_{2 \mathrm{j}} \mathrm{SRI}_{\mathrm{t}-\mathrm{j}}+\sum_{\mathrm{j}=1}^{\mathrm{k}} \lambda_{2 \mathrm{j}} \mathrm{LTS}_{\mathrm{t}-\mathrm{j}}+\sum_{\mathrm{j}=1}^{\mathrm{k}} \gamma_{2 \mathrm{j}} \mathrm{LINF}_{\mathrm{t}-\mathrm{j}}+\sum_{\mathrm{j}=1}^{\mathrm{k}} \delta_{2 \mathrm{j}} \mathrm{LER}_{\mathrm{t}-\mathrm{j}}+\sum_{\mathrm{j}=1}^{\mathrm{k}} \theta_{2 \mathrm{j}} \mathrm{LM}_{\mathrm{t}-\mathrm{j}}+\mathrm{u}_{2 \mathrm{t}} \\
& \mathrm{LINF}_{\mathrm{t}} \alpha_{3}+\sum_{\mathrm{j}=1}^{\mathrm{k}} \beta_{3 \mathrm{j}} \mathrm{SRI}_{\mathrm{t}-\mathrm{j}}+\sum_{\mathrm{j}=1}^{\mathrm{k}} \lambda_{3 \mathrm{j}} \mathrm{LTS}_{\mathrm{t}-\mathrm{j}}+\sum_{\mathrm{j}=1}^{\mathrm{k}} \gamma_{3 \mathrm{j}} \mathrm{LINF}_{\mathrm{t}-\mathrm{j}}+\sum_{\mathrm{j}=1}^{\mathrm{k}} \delta_{3 \mathrm{j}} \mathrm{LER}_{\mathrm{t}-\mathrm{j}}+\sum_{\mathrm{j}=1}^{\mathrm{k}} \theta_{3 \mathrm{j}} \mathrm{LM}_{\mathrm{t}-\mathrm{j}}+\mathrm{u}_{3 \mathrm{t}} \\
& \mathrm{LER}_{\mathrm{t}} \alpha_{4}+\sum_{\mathrm{j}=1}^{\mathrm{k}} \beta_{4 \mathrm{j}} \mathrm{SRI}_{\mathrm{t}-\mathrm{j}}+\sum_{\mathrm{j}=1}^{\mathrm{k}} \lambda_{4 \mathrm{j}} \mathrm{LTS}_{\mathrm{t}-\mathrm{j}}+\sum_{\mathrm{j}=1}^{\mathrm{k}} \gamma_{4 \mathrm{j}} \mathrm{LINF}_{\mathrm{t}-\mathrm{j}}+\sum_{\mathrm{j}=1}^{\mathrm{k}} \delta_{4 \mathrm{j}} \mathrm{LER}_{\mathrm{t}-\mathrm{j}}+\sum_{\mathrm{j}=1}^{\mathrm{k}} \theta_{4 \mathrm{j}} \mathrm{LM}_{\mathrm{t}-\mathrm{j}}+\mathrm{u}_{4 \mathrm{t}} \\
& \mathrm{LM}_{\mathrm{t}}=\alpha_{5}+\sum_{\mathrm{j}=1}^{\mathrm{k}} \beta_{5 \mathrm{j}} \mathrm{SRI}_{\mathrm{t}-\mathrm{j}}+\sum_{\mathrm{j}=1}^{\mathrm{k}} \lambda_{5 \mathrm{j}} \mathrm{LTS}_{\mathrm{t}-\mathrm{j}}+\sum_{\mathrm{j}=1}^{\mathrm{k}} \gamma_{5 \mathrm{j}} \mathrm{LINF}_{\mathrm{t}-\mathrm{j}}+\sum_{\mathrm{j}=1}^{\mathrm{k}} \delta_{5 \mathrm{j}} \mathrm{LER}_{\mathrm{t}-\mathrm{j}}+\sum_{\mathrm{j}=1}^{\mathrm{k}} \theta_{5 \mathrm{j}} \mathrm{LM} 3_{\mathrm{t}-\mathrm{j}}+\mathrm{u}_{5 \mathrm{t}}
\end{aligned}
$$


where: $\alpha_{n}$ is the intercept; $\beta_{n}, \lambda_{n}, \gamma_{n}, \delta_{n}$ and $\theta_{n}$ are the coefficients; $\mathrm{k}$ is number of lags and $u$ 's are the stochastic error terms (known as shocks in a VAR model). Before estimating the above equations, the Augmented Dickey Fuller (ADF) test was used to test for the unit root in the variables. If the variables have a unit root a co-integration test is generally undertaken to establish whether non-stationary variables move together over time and have a linear combination (Brooks, 2008). This study used the Johansen's multivariate co-integrating VAR approach to identify whether there is a long run relationship between the variables. If the co-integration test indicates that variables are not co-integrated, we will proceed with the VAR model. Alternatively, the following VECM will be estimated.

$$
\begin{aligned}
& \Delta \mathrm{LSI}_{\mathrm{t}}=\alpha_{1}+\sum_{\mathrm{j}=1}^{\mathrm{k}} \beta_{1 \mathrm{j}} \Delta \mathrm{SRI}_{\mathrm{t}-\mathrm{j}}+\sum_{\mathrm{j}=1}^{\mathrm{k}} \lambda_{1 \mathrm{j}} \Delta \mathrm{TS}_{\mathrm{t}-\mathrm{j}}+\sum_{\mathrm{j}=1}^{\mathrm{k}} \gamma_{1 \mathrm{j}} \Delta \mathrm{LINF}_{\mathrm{t}-\mathrm{j}}+\sum_{\mathrm{j}=1}^{\mathrm{k}} \delta_{1 \mathrm{j}} \Delta \mathrm{LER}_{\mathrm{t}-\mathrm{j}}+\sum_{\mathrm{j}=1}^{\mathrm{k}} \theta_{1 \mathrm{j}} \Delta \mathrm{LM}_{\mathrm{t}-\mathrm{j}}+ \\
& \varphi_{1} \mathrm{u}_{1 \mathrm{t}-1}+\mathrm{e}_{1} \\
& \Delta \mathrm{LTS}_{\mathrm{t}}=\alpha_{2}+\sum_{\mathrm{j}=1}^{\mathrm{k}} \beta_{2 \mathrm{j}} \Delta \mathrm{SRI}_{\mathrm{t}-\mathrm{j}}+\sum_{\mathrm{j}=1}^{\mathrm{k}} \lambda_{2 \mathrm{j}} \Delta \mathrm{TS}_{\mathrm{t}-\mathrm{j}}+\sum_{\mathrm{j}=1}^{\mathrm{k}} \gamma_{2 \mathrm{j}} \Delta \mathrm{LINF}_{\mathrm{t}-\mathrm{j}}+\sum_{\mathrm{j}=1}^{\mathrm{k}} \delta_{2 \mathrm{j}} \Delta \mathrm{LER}_{\mathrm{t}-\mathrm{j}}+\sum_{\mathrm{j}=1}^{\mathrm{k}} \theta_{2 \mathrm{j}} \Delta \mathrm{LM}_{\mathrm{t}-\mathrm{j}}+ \\
& \varphi_{2} \mathrm{u}_{2 \mathrm{t}-1}+\mathrm{e}_{2} \\
& \Delta \operatorname{LINF}_{\mathrm{t}}=\alpha_{3}+\sum_{\mathrm{j}=1}^{\mathrm{k}} \beta_{3 \mathrm{j}} \Delta \mathrm{SRI}_{\mathrm{t}-\mathrm{j}}+\sum_{\mathrm{j}=1}^{\mathrm{k}} \lambda_{3 \mathrm{j}} \Delta \mathrm{LTS}_{\mathrm{t}-\mathrm{j}}+\sum_{\mathrm{j}=1}^{\mathrm{k}} \gamma_{3 \mathrm{j}} \Delta \mathrm{LINF}_{\mathrm{t}-\mathrm{j}} \sum_{\mathrm{j}=1}^{\mathrm{k}} \delta_{3 \mathrm{j}} \Delta \mathrm{LER}_{\mathrm{t}-\mathrm{j}}+\sum_{\mathrm{j}=1}^{\mathrm{k}} \theta_{3 \mathrm{j}} \Delta \mathrm{LM}_{\mathrm{t}-\mathrm{j}}+ \\
& \varphi_{3} \mathrm{u}_{3 \mathrm{t}-1}+\mathrm{e}_{3} \\
& \Delta \mathrm{LER}_{\mathrm{t}}=\alpha_{4}+\sum_{\mathrm{j}=1}^{\mathrm{k}} \beta_{4 \mathrm{j}} \Delta \mathrm{SRI}_{\mathrm{t}-\mathrm{j}}+\sum_{\mathrm{j}=1}^{\mathrm{k}} \lambda_{4 \mathrm{j}} \Delta \mathrm{LTS}_{\mathrm{t}-\mathrm{j}}+\sum_{\mathrm{j}=1}^{\mathrm{k}} \gamma_{4 \mathrm{j}} \Delta \mathrm{LINF}_{\mathrm{t}-\mathrm{j}} \sum_{\mathrm{j}=1}^{\mathrm{k}} \delta_{4 \mathrm{j}} \Delta \mathrm{LER}_{\mathrm{t}-\mathrm{j}}+\sum_{\mathrm{j}=1}^{\mathrm{k}} \theta_{4 \mathrm{j}} \Delta \mathrm{LM} 3_{\mathrm{t}-\mathrm{j}}+ \\
& \varphi_{4} \mathrm{u}_{4 \mathrm{t}-1}+\mathrm{e}_{4} \\
& \Delta \mathrm{LM}_{\mathrm{t}}=\alpha_{5}+\sum_{\mathrm{j}=1}^{\mathrm{k}} \beta_{5 \mathrm{j}} \Delta \mathrm{SRI}_{\mathrm{t}-\mathrm{j}}+\sum_{\mathrm{j}=1}^{\mathrm{k}} \lambda_{5 \mathrm{j}} \Delta \mathrm{LTS}_{\mathrm{t}-\mathrm{j}}+\sum_{\mathrm{j}=1}^{\mathrm{k}} \gamma_{5 \mathrm{j}} \Delta \mathrm{LINF}_{\mathrm{t}-\mathrm{j}} \sum_{\mathrm{j}=1}^{\mathrm{k}} \delta_{5 \mathrm{j}} \Delta \mathrm{LER}_{\mathrm{t}-\mathrm{j}}+\sum_{\mathrm{j}=1}^{\mathrm{k}} \theta_{5 \mathrm{j}} \Delta \mathrm{LM}_{\mathrm{t}-\mathrm{j}}+ \\
& \varphi_{5} \mathrm{u}_{5 \mathrm{t}-1}+\mathrm{e}_{5}
\end{aligned}
$$

where: $\Delta$ is the first difference operator, $u_{1 t-1} \ldots u_{5-1}$ are error correction terms and $\varphi_{1} \ldots \varphi_{5}$ are error correction coefficients. These error correction coefficients are expected to capture the adjustments of change in the variables towards long-run equilibrium, while the coefficients, $\beta_{n}, \lambda_{n}, \gamma_{n}, \delta_{n}$ and $\theta_{n}$ are expected to capture the short-run dynamics of the model. The number of lags (k) will be selected based on Akaike Information Criterion (AIC), or Schwarz-Boyesian Information Criterion (SBIC) (Brooks, 2008). Before interpreting VCM results, diagnostic tests such as autocorrelation, hetroscedasticity, normality and parameter stability tests will be conducted to check whether the stochastic properties of the model are met (Maddala, 2001). Finally, variance decompositions will be used to trace out the responsiveness of SRI Index to shocks in macroeconomic stability variables.

\section{EMPIRICAL FINDINGS}

\subsection{Preliminary Analysis}

Table 1 show results of correlation analysis. A correlation coefficient is a number between -1 and +1 which shows the magnitude of a relationship between two variables. The higher the absolute value of the coefficient, the stronger the strength of the relationship is. Correlation between LSRI (log of SRI) and other 3 variables (LM3 (Log of money supply), LER (Log of exchange rate) and LCPI ( $\log$ of CPI) is significant at the 5\% level of significance. However, the correlation between LSRI and LTS (log of term spread) is not significant. This suggests that there is a high level of association between the log of the SRI Index and the log of other variables except the log of the term structure. Furthermore, the correction between LSRI and other variables, except LER, is observed; suggesting that there is a negative correlation between the log of the SRI index and the log of the real effective exchange rates.

Table 1: Pairwise Correlations

\begin{tabular}{lccccc}
\hline & LSRI & LM3 & LER & LCPI & LTS \\
\hline LSRI & 1.0000 & & & & \\
LM3 & $0.8741^{*}$ & 1.0000 & & & \\
LER & $-0.6324^{*}$ & $-0.7971^{*}$ & $-0.7480^{*}$ & 1.0000 & \\
LCPI & $0.7897^{*}$ & $0.9731^{*}$ & 0.1455 & $0.4136^{*}$ & 1.0000 \\
LTS & 0.0453 & $0.2470^{*}$ & &
\end{tabular}

* significant at the $5 \%$ level of significance 
Table 2 shows the results of the augmented dickey-fuller unit root test. The results show that at the 5\% level of significance all variables had a unit root in their levels, but the first difference of all the variables become stationary at the $1 \%$ level of significance. This indicates that all variables are integrated of order one. The next step is therefore to test for co-integration.

Table 2: Augmented Dickey-Fuller Unity Root Test

\begin{tabular}{lcccc}
\hline \multirow{2}{*}{ Variables } & \multicolumn{2}{c}{ Level } & \multicolumn{2}{c}{ First Difference } \\
\cline { 2 - 5 } & t-Statistic & P-values & t-Statistic & P-values \\
\hline LSRI & -2.270024 & 0.1837 & -7.638325 & 0.0000 \\
LCPI & -0.082647 & 0.9476 & -7.530742 & 0.0000 \\
LER & -1.577618 & 0.4904 & -10.62391 & 0.0000 \\
LTS & -1.077368 & 0.7225 & -8.090660 & 0.0000 \\
LM3 & -2.609569 & 0.0943 & -10.60907 & 0.0000 \\
\hline
\end{tabular}

Johansen co-integration Trace and Max-eigenvalue tests (Table 3) indicate that there are 2 co-integrating equations at the 0.05 level of significance. Meaning that, there is a long-run association between the variables. These results are similar to previous findings of a long-run relationship between the stock market (or a stock market's sector) and macroeconomic variables (Chung \& Shin, 1999; Garcia \& Liu, 1999; Kemboi \& Tarus, 2012; Mukherjee \&Naka, 1995). The co-integrating equation for LSRI (Equation 13) indicates that CPI, LCPI, LM3 and LER have a negative long-run effect on the LSRI; while LTS has a long-run positive effect on LSRI. These results are consistent with previous findings (Chung \& Shin 1999; Chen, Roll \& Ross, 1986; Jefferis \& Okeahalam, 2000; Mukherjee \& Naka, 1995; Mookerjee \& Qiao, 1997; Udoka \& Anyingang, 2013) which found similar long-run relationships between the stock market development and these macroeconomic variables.

LSRI $=-0.3904 \mathrm{LCPI}-0.9430 \mathrm{LER}+10.4189 \mathrm{LTS}-1.4450 \mathrm{LM} 3$

Table 3: Summary of Johansen Co-Integration Test Statistics

\begin{tabular}{lcccc}
\hline \multirow{2}{*}{$\mathbf{H}_{\mathbf{0}}$ : Number of Co-Integrating Equations } & \multicolumn{2}{c}{ Trace Test } & \multicolumn{2}{c}{ Maximum Eigenvalue } \\
\cline { 2 - 5 } & Trace Statistic & P-values* & Max-Eigen Statistic & P-values* \\
\hline None & 108.5286 & 0.0000 & 45.96061 & 0.0012 \\
At most 1 & 62.56797 & 0.0012 & 34.22468 & 0.0061 \\
At most 2 & 28.34329 & 0.0728 & 18.32944 & 0.1180 \\
At most 3 & 10.01385 & 0.2797 & 5.979258 & 0.6159 \\
At most 4 & 4.034589 & 0.0446 & 4.034589 & 0.0446 \\
\hline
\end{tabular}

* MacKinnon-Haug-Michelis (1999) p-values

\subsection{Vector Error Correction Model}

In general, the existence of a co-integrating relationship between the SRI Index and the combination of selected macroeconomic variables suggests that these variables explain the long run equilibrium in the SRI Index. In the short run, macroeconomic variables such as inflation, real effective exchange rate and money supply are not significant in predicting changes in SRI Index. However, the SRI Index may be significant in predicting short run change in term spread. To confirm short-run relationship, a pairwise granger causality test between SRI Index and these variables is conducted. A pairwise granger causality (Table 4) shows that there is a one-way causality from real effective exchange rate to the SRI Index, and a two-way causality between the SRI Index and term spread. The causality between the SRI Index and term spread confirms the short run results from the VCM. However, the causality between the real exchange rate and the SRI Index is not in line with the VCM results. To solve this conflict, we conducted a variance decomposition analysis for SRI Index. Variance decomposition analysis ${ }^{1}$ revealed that shocks in the SRI Index not are explained by shocks from any of the selected macroeconomic variables. This confirmed the VCM results that macroeconomic variables are not significant in predicting short-run changes in the SRI Index. These results are supported by previous findings that socially responsible investors mostly focus on earning long-term profit (Herringer et al. 2009).

\footnotetext{
${ }^{1}$ variance decomposition tables can be requested from the author. 
Table 4: Pairwise Granger Causality Tests (Lags: 3)

\begin{tabular}{lcc}
\hline \multicolumn{1}{c}{ Null Hypothesis: } & F-Statistic & Prob. \\
\hline$\Delta$ LCPI does not Granger Cause $\Delta$ LSRI & 0.4979 & 0.6846 \\
$\Delta$ LSRI does not Granger Cause $\Delta$ LCPI & 0.9338 & 0.4277 \\
$\Delta$ LEX does not Granger Cause $\Delta$ LSRI & $3.7211^{*}$ & 0.0141 \\
$\Delta$ LSRI does not Granger Cause $\Delta$ LEX & 1.9345 & 0.1294 \\
$\Delta$ LM3 does not Granger Cause $\Delta$ LSRI & 1.4251 & 0.2404 \\
$\Delta$ LSRI does not Granger Cause $\Delta$ LM3 & 1.0667 & 0.3672 \\
$\Delta$ LTS does not Granger Cause $\Delta$ LSRI & $3.5521 *$ & 0.0174 \\
$\Delta$ LSRI does not Granger Cause $\Delta$ LTS & $3.3792 *$ & 0.0216 \\
\hline
\end{tabular}

**Significant at $1 \%$ level, *Significant at $5 \%$ level

Having established that our variables are co-integrated, VECM (Equations 8 to 12) is undertaken in order to establish the adjustment towards long-run equilibrium, and the short-run dynamics between the variables. VECM results in Table 5 show that the first co-integrating equation (CointEq1) has two significant coefficients (LTS and LM3). However, LTS is the most significant coefficient, with a t-value of -4.45621 and has a correct negative sign. This suggests that the term spread equation constitutes the true co-integrating relationship in the first co-integrating vector. In the second co-integrating equation (CointEq2), there are four significant variables (LSRI, LCPI, LTS and LM3). However, LSRI is the only significant variable with a negative adjustment coefficient, meaning that it has a correct sign. This suggests that SRI Index shows strong evidence of error correction to the second co-integrating equation. The interpretation of the two co-integrating equations is that the first equation explains the long run equilibrium in term spread, while the second equation explains the long-run equilibrium in SRI Index.

\begin{tabular}{|c|c|c|c|c|c|}
\hline Error Correction & $\Delta$ LSRI & $\Delta \mathrm{LCPI}$ & $\Delta$ LER & $\Delta$ LTS & $\Delta$ LM3 \\
\hline \multirow[t]{2}{*}{ CointEq1 } & -0.027439 & 0.004851 & -0.029735 & $-0.012253^{*}$ & $0.037866^{*}$ \\
\hline & {$[-0.67183]$} & [1.26569] & {$[-0.73565]$} & {$[-4.45621]$} & {$[2.77676]$} \\
\hline \multirow[t]{2}{*}{ CointEq2 } & $-0.509032 *$ & $0.054005^{*}$ & -0.294366 & $0.027342 *$ & $0.103299 *$ \\
\hline & {$[-3.38558]$} & [3.82792] & {$[-1.97831]$} & {$[2.70130]$} & {$[2.05772]$} \\
\hline \multirow[t]{2}{*}{$\Delta$ LSRI(-1) } & 0.168150 & 0.009909 & 0.070469 & $0.022526^{*}$ & 0.037664 \\
\hline & {$[1.49741]$} & [0.94044] & {$[0.63410]$} & [2.97969] & {$[1.00454]$} \\
\hline \multirow[t]{2}{*}{$\Delta \operatorname{LSRI}(-2)$} & -0.090758 & 0.013268 & 0.014554 & $0.028075^{*}$ & -0.052953 \\
\hline & {$[-0.78493]$} & [1.22289] & {$[0.12718]$} & [3.60682] & {$[-1.37164]$} \\
\hline \multirow[t]{2}{*}{$\Delta \mathrm{LCPI}(-1)$} & 1.462644 & 0.021308 & 0.879147 & -0.042279 & $-0.926477 *$ \\
\hline & [1.09704] & {$[0.17032]$} & [0.66629] & {$[-0.47104]$} & {$[-2.08123]$} \\
\hline \multirow[t]{2}{*}{$\Delta \mathrm{LCPI}(-2)$} & 0.022937 & -0.025234 & -1.183477 & 0.038269 & -0.090758 \\
\hline & {$[0.01768]$} & {$[-0.20725]$} & {$[-0.92161]$} & [ 0.43809$]$ & {$[-0.20949]$} \\
\hline \multirow[t]{2}{*}{$\Delta \operatorname{LEX}(-1)$} & 0.068821 & -0.000631 & -0.094572 & -0.014521 & -0.077556 \\
\hline & {$[0.58874]$} & {$[-0.05749]$} & {$[-0.81750]$} & {$[-1.84525]$} & {$[-1.98713]$} \\
\hline \multirow[t]{2}{*}{$\Delta \operatorname{LEX}(-2)$} & 0.009879 & -0.017723 & 0.000467 & -0.002079 & -0.011801 \\
\hline & {$[0.08791]$} & {$[-1.68082]$} & {$[0.00420]$} & {$[-0.27479]$} & {$[-0.31455]$} \\
\hline \multirow[t]{2}{*}{$\Delta \mathrm{LTS}(-1)$} & -3.019362 & $0.408724 *$ & 0.335795 & 0.153538 & 0.986164 \\
\hline & {$[-1.89737]$} & [ 2.73721$]$ & {$[0.21322]$} & [ 1.43318$]$ & [ 1.85604$]$ \\
\hline \multirow[t]{2}{*}{$\Delta \operatorname{LTS}(-2)$} & 0.789505 & 0.189945 & 1.771008 & -0.043159 & 0.565041 \\
\hline & [ 0.45524$]$ & [1.16722] & [ 1.03187$]$ & {$[-0.36967]$} & {$[0.97581]$} \\
\hline \multirow[t]{2}{*}{$\Delta \mathrm{LM} 3(-1)$} & 0.425663 & -0.002324 & 0.434844 & -0.030944 & -0.149281 \\
\hline & [1.34701] & {$[-0.07838]$} & [1.39046] & {$[-1.45455]$} & {$[-1.41486]$} \\
\hline \multirow[t]{2}{*}{$\Delta \mathrm{LM} 3(-2)$} & 0.387631 & 0.014246 & 0.059121 & -0.015836 & 0.069257 \\
\hline & [1.24124] & {$[0.48616]$} & [0.19129] & {$[-0.75324]$} & {$[0.66421]$} \\
\hline
\end{tabular}

t-statistics in [ ], *significant at the 5\% level, 2 legs were selected based on AIC

Short run dynamics for $\triangle$ LSRI equation are not significant; meaning that past changes in LCPI, LER, LTS and LM3 have no explanatory power on current $\triangle \mathrm{LSR}$. This suggests that past changes in macroeconomic variables do not cause change in current change in SRI Index. In the inflation equation ( $\Delta$ LCPI), there is only one significant variable (the first lag of $\Delta$ LTS). This suggests that past changes in term spread affects current change in the inflation rate. In the real effective exchange equation $(\Delta \mathrm{LER})$, all short run coefficients are not statistically significant;

${ }^{2}$ LM tests revealed that there are no autocorrelations, nor hetroscedasticity in the VECM residuals. 
indicating that past changes in SRI Index and other macroeconomic variables do not affect the current change in real effective exchange rate. In the term spread equation ( $\triangle \mathrm{LTS}$ ), both lags of $\Delta$ LSRI are significant; suggesting that pat changes in SRI Index affects current changes in term spread. This is line with theory because changes in interest rate affect investment decisions and changes in investment decisions affect the demand for SRI. The money supply equation $(\triangle \mathrm{LM} 3)$ suggests that past changes in the inflation rate affect current changes in money supply.

\section{CONCLUSION}

The aim of the study reported in this article was to investigate the role of macroeconomic stability variables in explaining the behavior of the growing SRI sector in South. A co-integration approach, VCM and causality tests were used to assess the relationship between the SRI Index and a set of macroeconomic variables (consumer price index (CPI), real effective exchange rate, money supply and term spread (difference between long term and shortterm interest rates). Johansen co-integration test revealed that there is a long-run association between the variables. The co-integrating equation indicated that inflation, real effective exchange rate and money supply have a negative long-run effect on SRI Index while term spread had a long-run positive effect on SRI Index. Thus, this paper emphasised that there is a long-run relationship between the SRI Index and a combination of the selected macroeconomic variables.

In the short run, macroeconomic variables such as inflation, real effective exchange rate and money supply were not significant in predicting changes in SRI Index. This was confirmed by variance decomposition analysis which revealed that shocks in the SRI Index were not explained by shocks from any of the selected macroeconomic variables. There was little evidence on the effect of macroeconomic changes on SRI in the short-run. However, there was a significant short-run relationship between the SRI Index and term spread. This relationship was confirmed by a pairwise granger causality test which found a two-way causality between the SRI Index and term spread. The general conclusion of the study is that there is a long-run relationship between macroeconomic variables and the SRI sector in South Africa. This confirms previous findings that the effect SRI is mostly observed in the long-run. These findings suggest that policymakers should consider the implications of macroeconomic policies on the SRI sector.

\section{AUTHOR INFORMATION}

Paul F. Muzindutsi is a PhD Candidate at North-West University. His research interests include finance and development economics. E-mail: paul.muzindutsi@nwu.ac.za

Tshediso J. Sekhampu is a senior lecturer in economics at the Vaal Triangle Campus of North-West University. His research interest is on poverty and socio-economic studies. E-mail: joseph.sekhampu@nwu.ac.za (Corresponding author)

\section{REFERENCES}

1. Brook, C. (2008). Introductory Econometrics for Finance (2nd ed.). UK: Cambridge University Press.

2. Chan, N. H. (2010). Time Series: Applications to Finance with R and S-Plus (2nd ed.). New Jersey: John Wiley \& Sons.

3. Chen, N. F., Roll, R., \& Ross, S. A. (1986). Economic forces and the stock market. Journal of Financial Research, 24(4), 587-602.

4. Dominguez, K., \& Tesar, L. (2001). A reexamination of exchange-rate exposure. American Economic Review, 91(2), 396-399.

5. Flores-Araoz, M. (2011). Corporate Social Responsibility in South Africa: More than a nice intention. Consultancy Africa Intelligence. Retrieved September 2, 2012, from http://www.consultancyafrica.com/index.php?option=com content $\&$ view=article $\&$ id $=835$ : corporatesocial-responsibility-in-south-africa-more-than-a-nice-intention\&catid=82:african-industry-abusiness\&Itemid $=266$

6. Garcia, V., \& Liu, L. (1999). Macroeconomic determinants of stock market development. Journal of Applied Economics, 2(1), 29-59. 
7. Gladysek, O., \& Chipeta, C. (2012). The impact of Socially Responsible Investment Index constituent announcements on firm price: evidence from the JSE. South African Journal of Economic and Management Sciences, 15(4), 429-439.

8. Gupta, R., \& Modise, M. (2011). Macroeconomic variables and South African stock return predictability. Department of Economics Working Paper Series.

9. Herringer, A., Firer, C., \& Viviers, S. (2009). Key challenges facing the Social Responsible Investment (SRI) sector in South Africa. Investment Analysis Journal, 7, 11-26.

10. Jefferis, K., \& Okeahalam, C. (2000). The impact of economic fundamentals on stock markets in Southern Africa. Development Southern Africa, 17(1), 23-51.

11. JSE. (2004). JSE SRI Index: Background and Selection Criteria 2004. Retrieved 02 10, 2013, from http://www.jse.co.za/About-Us/SRI/Criteria.aspx

12. JSE. (2011). JSE SRI Index: background and selection criteria. Retrieved 02 10, 2013, from http://www.jse.co.za/About-Us/SRI/Criteria.aspx

13. JSE. (2012). Introduction to SRI Index. Retrieved 02 10, 2013, from http://www.jse.co.za/AboutUs/SRI/Introduction to SRI_Index.aspx

14. Kemboi, J., \& Tarus, D. (2012). Macroeconomic determinants of stock market development in emerging markets: evidence from Kenya. Research Journal of Finance and Accounting, 3(5), 57-68.

15. Maddala, G. (2001). Introduction to Econometrics (3rd ed.). West Sussex: John Wiley \& Sons, Ltd.

16. Maysam, R., Howe, L., \& Hamzah, M. (2004). Relationship between macroeconomic variables and stock market indices: cointegration evidence from stock exchange of Singapore's All-S Sector Indices. Journal Pengurusan, 24, 47-77.

17. Mookerjee, R., \& Qiao Yu, Q. (1997). Macroeconomic variables and stock prices in a small open economy: the case of Singapore. Pacific-Basin Finance Journal, 5, 377-388.

18. Mukherjee, T., \& Naka, A. (1995). Dynamic relations between macroeconomic variables and the Japanese Stock Market: an application of a Vector Error Correction Model. The Journal of Financial Research, 18(2), 223-237.

19. Muzindutsi, P., \& Niyimbanira, F. (2012). The exchange rate risk in the Johannesburg Stock Market: an application of the arbitrage pricing model. Journal of Global Business and Technology, 81(1), 60-70.

20. Naceur, S., Ghazouani, S., \& Omran, M. (2007). The determinants of stock market development in the Middle-Eastern and North African region. Managerial Finance, 7, 477-489.

21. Patterson, K. (2000). An introduction to applied econometrics: A time series approach. London: Macmillian Press Ltd.

22. Reese, B. (1993). The arbitrage pricing theory in South Africa: an empirical study of the effect of prespecified risk factors on share prices on the Johannesburg Stock Exchange. Master's Thesis. Durban: University of Natal.

23. Udoka, C., \& Anyingang, R. (2013). Stock price volatility and its effect on the Nigerian Stock Market (1980-2009). International Journal of Management, 30(1), 127-141.

24. Viviers, S. (2007). Critical assessment of socially responsible investing in South Africa. Doctoral Thesis. Port Elizabeth: Nelson Mandela Metropolitan University.

25. Viviers, S., Bosch, J., Smith, E., \& Buijs, A. (2008). The risk-adjusted performance of responsible investment funds in South Africa. Investments Analysts Journal, 68, 1-17.

26. Williams, G. (2007). Some determinants of the Socially Responsible Investment decision: a cross-country study. The Journal of Behavioral Finance, 8(1), 43-57.

27. Yang, Y., \& Yi, M. (2008). Does financial development cause economic growth? Implication for policy in Korea. Journal of Policy Modeling, 30, 827-840.

28. Yartey, C. (2008). The determinants of stock market development in emerging economies: Is South Africa different?. Retrieved 02 10, 2013, from http://www.imf.org/external/pubs/ft/wp/2008/wp0832.pdf 